\title{
Perverse Transformation: Railway Development and the Shaping of Queensland Society, 1880-1901
}

\section{Bradley Bowden*}

The railways played a central role in the development of New World societies. In the United States, Shelton Stromquist found that in the American Mid-West and West, two sorts of communities were formed. The first were "merchant towns" under the domination of commercial interests and hostile to organised labour. The other were "railway towns." These towns, within which railway workers were numerically significant, were supportive of labour militancy. In using census to explore the social impact of railway development on Queensland society between 1880 and 1901, however, this study finds that Queensland's railways produced only "merchant towns." Perversely, the railways also impeded local manufacturing as Queensland's "railway towns" increasingly acted as conduits of imported goods to the colony's rural population.

When work on Queensland's first railroad commenced at Ipswich in 1864 the line ran westward rather than towards Brisbane, 40 kilometres eastward. Four years later, after financial difficulties halted work, the western terminus was located 170 kilometres away at Dalby (see Map). In the heart of the Darling Downs, with its rich black soil, Dalby initially flourished. By 1876, when the line recommenced its march, the town had 1,870 inhabitants. Thereafter, progress faltered. Increasingly, Dalby was converted into a town of merchants who purveyed imported goods to local farmers. Whereas Dalby was home to 17 metal tradespeople in 1886, by 1901 only eight remained. Work in food and drink manufacture, life's staples, fell from 28 to ten. As jobs disappeared the population shrank. By 1901, only 1,406 people remained. For a while it seemed that Dalby's loss was simply Roma's gain as the latter became the new terminus in 1880. Even when the southern line was extended to Charleville (1888) and Cunnamulla (1898), Roma remained a major hub. For while most of the 270 kilometres separating Roma and Dalby is flinty cypress pine country, Roma provides a portal to Queensland's brigalow plains - a land of wattle, open forest and grassland. In 1901, Roma's population $(2,664)$ was much larger than that recorded in $1886(1,727)$. Between 1886 and 1901 the number of railway workers who lived in or about Roma also rose by 45.5 per cent to 163 . Despite such gains, Roma became, like Dalby, a town principally composed of merchants and shopkeepers. By 1901 the town boasted 318 members of the mercantile class, compared to 26 in 1886. Little was locally-made, there being only 38 workers engaged in food and drink manufacture in 1901. Other western rail hubs witnessed little direct railroad employment. In 1901 the engine crews at Charleville, Emerald and Hughenden, numbered 13, 12 and 14 respectively. When we add in the 15 based in Roma, this total amounted to 8.5 per cent of Queensland's engine crew labour force of $637 .{ }^{1}$

The author would like to thank Labour History's two anonymous referees.

1. Queensland Government, Seventh Census of Queensland, 1886 (Brisbane: Queensland Government

Printer, 1887), 39-40; Queensland Government, Ninth Census of Queensland, 1901 (Brisbane:

Queensland Government Printer, 1902), 258-277. 
Over recent decades Australian labour historians have paid much attention to railroad communities: Ipswich and Rockhampton in Queensland, Midland in Western Australia and, in New South Wales (NSW), Lithgow and the suburbs adjacent to Sydney's Eveleigh workshops. ${ }^{2}$ Such research is supplemented by institutional studies such as Hearn's history of the Australian Railways Union in NSW. ${ }^{3}$ Others have highlighted how the railway vote sustained Labor's rural support. ${ }^{4}$ Missing from this body of research is an appraisal of how railroad development shaped local economic activity and, through this, the varying ways in which communities responded to trade union activity. Such questions have, however, long been considered by United States (US) labour historians, most notably Gutman and Stromquist. Whereas Gutman believed most "small railroad towns" were supportive of labour militancy, ${ }^{5}$ Stromquist identified two types of railroad communities. The first, hostile to organised labour, were "market towns" dominated by mercantile interests. The second were "railway towns," supportive of unionism due to the dominance of railroad workers. ${ }^{6}$ In the case of Queensland, this study drawing upon census reports - finds that there were no "railroad towns" in the sense Stromquist discussed, ie towns in which railway workers were socially hegemonic. Instead, by truncating industrial development along the network, Queensland's railways restricted social diversification. In agricultural areas, there were farmers, merchants and not much else. In mining areas, there were miners, merchants and not much else. Perverse effects were also evident in the provincial towns most associated with railway work: Ipswich, Toowoomba, Maryborough, Rockhampton and Townsville. In 1886, those engaged as either railroad or metal workers in these centres totalled 2,565, easily exceeding the number of merchants and storekeepers $(1,220)$. Fifteen years later, when railway mileage was three times larger, merchants and storekeepers (and their employees) outnumbered those engaged in metal manufacture or railway work by 7,137 to 2,790 .

Why was it that in Queensland the railways curtailed rather than advanced manufacturing and what were the industrial consequences of this perverse effect?

2. Bradley Bowden, “'Some Mysterious Terror': The Relationship between Capital and Labour in Ipswich, 1861-96," Labour History, no. 72 (May 1997): 77-100; Bradley Bowden, "A Time 'the Like of Which was Never Before Experienced': A Time the Like of Which was Never Before Experienced in Ipswich, 1900-12," Labour History, no. 78 (May 2000): 71-93; Barbara Webster, “A 'Cosy Relationship' If You Had It: Queensland Labor's Arbitration System and Union Organising Strategies in Rockhampton, 1916-57," Labour History, no. 83 (November 2002): 89-106; Patrick Bertola and Bobbie Oliver, eds, The Workshops: A History of the Midland Government Railway Workshops (Crawley: University of Western Australia Press, 2006); Greg Patmore, "Localism and Labour: Lithgow 1869-1932," Labour History, no. 78 (May 2000): 53-70; Lucy Taksa, "Politics, Industrial Heritage and Working Life at Eveleigh," Labour History, no. 85 (November 2003): 65-88.

3. Mark Hearn, Working Lives: A History of the Australian Railways Union, NSW Branch (Sydney: Hale \& Iremonger, 1990); Greg Patmore, "The Origins of the National Union of Railwaymen," Labour History, no. 43 (November 1982): 44-52.

4. Geoff Robinson, When the Labor Party Dreams: Class, Politics and Policy in NSW 1930-32 (Melbourne: Australian Scholarly Publication, 2008); Jim Hagan and Ken Turner, A History of the Labor Party in New South Wales 1891-1991 (Melbourne: Longman Cheshire, 1991).

5. Herbert Gutman, "Trouble on the Railroads in 1873-74: Prelude to the 1877 Crisis?" Labor History 2 (1961): 215; Herbert Gutman, Work, Culture, and Society in Industrializing America (New York: Alfred A. Knopf, 1976).

6. Shelton Stromquist, "Enginemen and Shopmen: Technological Change and the Organization of Labor in an Era of Railroad Expansion," Labor History 24 (1983): 485-99; Shelton Stromquist, A Generation of Boomers: The Pattern of Railroad Labor Conflict in Nineteenth-Century America (Urbana and Chicago: University of Illinois Press, 1987).

7. Seventh Census of Queensland, 1886, 180-93; Ninth Census of Queensland, 1901, 258-59. 


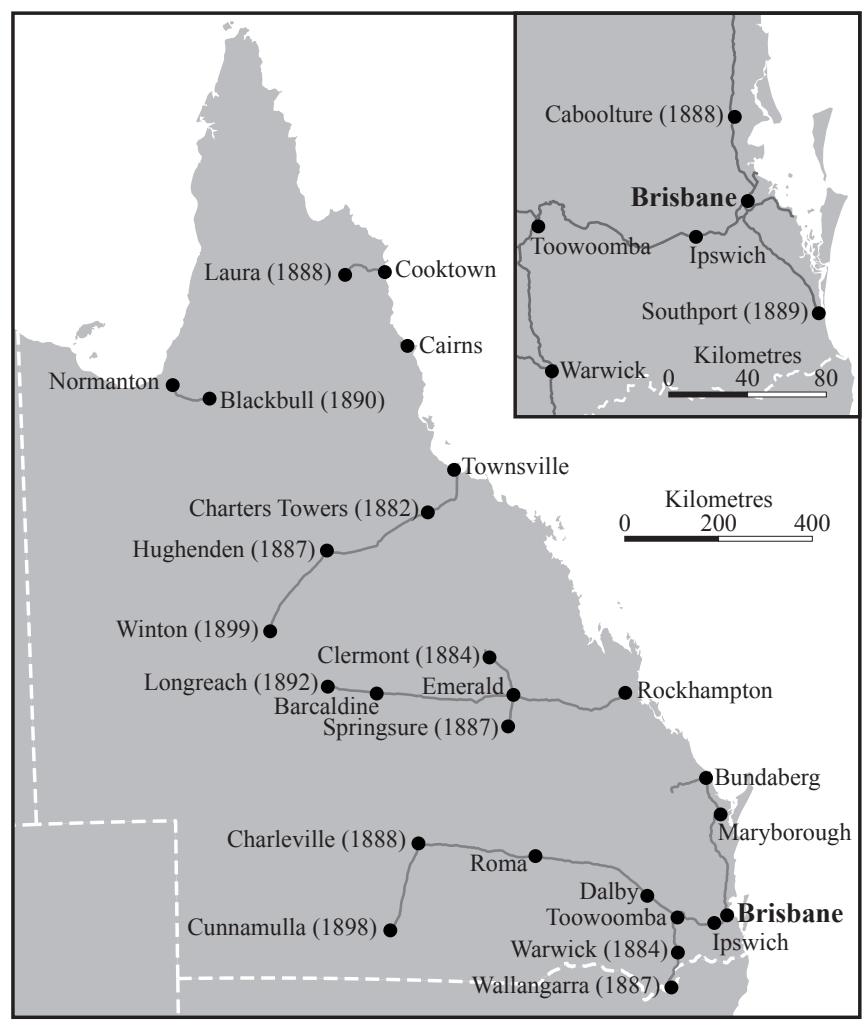

Historic Queensland Railways to 1900

Courtesy: MapGraphics, Brisbane

Seeking answers, this article locates Queensland's circumstance within a wider narrative, paying particular heed to the situation in the American West. There are two reasons for this comparative approach. First, nineteenth century railways were a global phenomenon, providing the sinews for emerging national and international markets. Second, if we are to draw, as this study does, on an extant US labour history literature, then we need to consider what it was that made Queensland's experience so different. In explanation, this paper argues that peculiarities of geography best explain differences. Paradoxically, Queensland's vastness resulted in comparatively short railway lines. Rather than radiating out from central hubs as occurred in southern colonies and in the American West, Queensland was characterised by a series of east-west systems, each based upon coastal towns. The distance between Rockhampton and Longreach, the western terminus for Queensland's central trunk system, was less than 700 kilometres (see Map). This was much less than the distance between Sydney and the NSW border town of Echuca (883 kilometres), which was hardly NSW's most remote terminus. Queensland distances were also dwarfed by those of the American West, where more than 1,500 kilometres separated Chicago and Cheyenne (Wyoming's capital). Shorter Queensland distances, and coastal termination, allowed for workforce concentration in eastern hubs, leaving towns elsewhere with a dearth of railroad employees. Coastal location also facilitated importation in preference to local manufacture. By thus encouraging mercantile 
activities in lieu of industrial ones, the railways helped shape a society where the urban working class and their unions were comparatively weak.

\section{Railroads and Place}

The study of railway communities has a long heritage. In the USA, much research has been directed towards understanding the social underpinnings of the great railroad strikes of 1873-74 and 1893-94 (the Pullman Boycott). In exploring this phenomenon, Gutman, Stromquist and others have emphasised the importance of geography. ${ }^{8}$ As Stromquist observed, conflict was fiercest in "the upper Midwest, the southern Great Plains, and in the northern Mountain states." ${ }^{\prime 9}$ What was most perceptive in Stromquist's Generation of Boomers, however, was his demonstration of how railroad communities could take very different social forms. Depending on whether or not railroad employees or merchant groups were socially dominant, railroad towns could treat labour militancy either benignly or hostilely.

Australian studies of the interrelationship between railway towns and labour organisation have had, as noted earlier, a narrower focus, considering individual communities rather than patterns of social variance. There has, however, been increased Australian interest in how place-based relations are forged in the first instance. ${ }^{10}$ In this regard, nineteenth century railroads played a seminal role. Whereas railroads spurred industrialisation in Western Europe and the American north-east, elsewhere, it is argued, they "skewed development," perpetuating "an unbalanced export-import trade." ${ }^{11}$ In Australia, Butlin described this tendency, in which colonial societies became dependent on a narrow range of trade-exposed activities, as sectoral disequilibrium. ${ }^{12}$ Such problems were most evident in rural regions. As both Harley and Dick's studies of the global wheat trade revealed, New World exports soon drove down prices in an oversupplied market, placing rural communities and shippers in an often precarious position..$^{13}$ In small to mid-sized western US towns, Gates and Fishlow suggest, railroads favoured growth of "commercial" and "distributive" activities over manufacturing; analysis that corresponds with this study's findings. ${ }^{14}$

Within the nineteenth century global economy, Australia differed from other societies in having government-owned railways. Theoretically, this should have made them very different from those of the United States where inter-firm

8. Gutman, "Trouble on the Railroads"; Stromquist, Generation of Boomers; Nick Salvatore, "Railroad Workers and the Great Strike of 1877: The View from a Small Midwestern City," Labor History 21 (1980): 522-45; David Papke, The Pullman Case: The Clash of Capital and Labor in Industrial America (Lawrence: University of Kansas Press, 1991); Richard Schneirov, Shelton Stromquist and Nick Salvatore, eds, The Pullman Strike and the Crisis of the 1890s (Chicago: University of Illinois Press, 1991).

9. Stromquist, Generation of Boomers, 30.

10. In particular, Bradon Ellem and John Shields, “Rethinking 'Regional Industrial Relations': Space, Place and the Social Relations at Work," Journal of Industrial Relations 41, no. 4 (1999): 536-60; Bradon Ellem and Susan McGrath-Champ, "Labor Geography and Labor History: Insights and Outcomes from a Decade of Cross-Disciplinary Dialogue," Labor History 53, no. 3 (2012): 355-72.

11. Shelton Stromquist, "Railroad Labor and the Global Economy: Historical Patterns," in Global Labour History: A State of the Art, ed. Jan Lucassen (Bern: Peter Lang, 2006), 623-48.

12. N. G. Butlin, Investment in Australian Economic Development 1861-1900 (Canberra: ANU Press, 1972), 407-408.

13. C. Knick Harley, "Transportation, the World Wheat Trade and the Kuznets Cycle 1850-1913," Explorations in Economic History 17 (1980): 218-50; Trevor Dick, "Canadian Wheat Production and Trade 1896-1930," Explorations in Economic History 17 (1980): 275-302.

14. Paul Gates, The Illinois Central and its Colonization Work (Cambridge, Mass.: Harvard University Press, 1934); Albert Fishlow, American Railroads and the Transformation of the Ante-Bellum Economy (Cambridge, Mass: Harvard University Press, 1965), 232-33. 
competition is seen as the main factor behind the "periodic catharsis" that regularly afflicted railway employment. ${ }^{15}$ By contrast, Australian railway development was widely perceived to be, as Samuel Griffith advised the Queensland Parliament in 1888, "necessarily a question of politics." ${ }^{16}$ According to Butlin, emphasis on rail's developmental capacity, rather than its profit-generating potential, was most evident in Queensland where governments were "preoccupied with the association of railway investment, immigration and land settlement." ${ }^{17}$

The view that Queensland development, whether in relation to the railroads or the economy more widely, is best explained through reference to politics is well established. According to pioneer labour activist, W. G. Spence, Queensland politics was dominated by squatters and speculators who exploited railway development so as to perpetrate "land steals." ${ }^{18}$ McQueen and Ferrier have similarly argued that Queensland history is one dominated by "reactionary" forces intent of steering development in the interests of a few. ${ }^{19}$ In terms of nineteenth century history, Thomas McIlwraith's career gives credence to this narrative. Serving as Premier (1879-82, 1888, 1893), Treasurer (1879-82, 1890-93) and Railways' Minister (1893-95), McIlwraith was certainly associated with many speculative proposals, including a Transcontinental railroad and a system of private railways funded by "land grants," both of which were stillborn. ${ }^{20}$ Despite this record we should be wary of concluding that the paucity of Queensland's industrial development resulted from financial conspiracy. McIlwraith, in particular, is a misrepresented figure. While he was associated with dubious railroad proposals, he was also responsible for the State Railways Management Act, 1888. Replicating Victorian legislation, this Act brought railway employment under civil service provisions. It also required the Commissioners to operate railroads on "commercial" principles. To maximise "development," Commissioners had to work lines "as will best conduce ... [agricultural] settlement." ${ }^{21}$ To facilitate manufacturing, Mcllwraith increased tariffs in 1888 from five to up to 15 per cent.

If we need to be wary of ascribing Queensland railroad development to crass financial motives we should also be slow to conclude that state ownership placed Queensland's railroads in a fundamentally different operational position to that of America's privately-owned entities. For while Queensland's railroads were initially developed to service the pastoral industry, by the 1890s the bulk of their rural trade - when measured by tonnage - was not wool but corn, wheat and other agricultural produce (see Figure 3). In consequence, Queensland's railroads found themselves in a broadly similar position to those of the American West. With freight wagons increasingly filled by grain, railroads - whether privately-owned or under

15. Stromquist, Generation of Boomers, 13-14. Stromquist draws on Julius Grodinsky, The Iowa Pool: A Study in Railroad Competition 1870-84 (Chicago: University of Chicago Press, 1950).

16. Oueensland Parliamentary Debates (hereafter QPD) 55 (1888): 132

17. Butlin, Investment in Australian Economic Development, 358.

18. W. G. Spence, Australia's Awakening (Melbourne \& Sydney: Worker Trustees, 1909), 268, 301.

19. Humphrey McQueen, "Foreword," in Radical Brisbane, ed. Raymond Evans and Carole Ferrier (Carlton North: Vulgar Press, 2004), 9; Carole Ferrier, "Afterword," in Evans and Ferrier, Radical Brisbane, 320.

20. D. B. Waterson, "Thomas Mcllwraith," in Queensland Political Portraits 1859-1952, ed. D. J. Murphy and R. B. Joyce (St Lucia: Queensland University Press, 1978), 119-42.

21. QPD 55 (1888): 133. 
government control - found the maintenance of freight rates near impossible as world wheat prices suffered a continuous decline in an oversupplied market.

In summary, therefore, there are two bodies of literature particularly relevant to this study and which this study broadly reinforces. The first is Stromquist's schema, which categorised communities along the nineteenth century railroad network as either "railroad" or "merchant" towns, depending on which groups were socially hegemonic. The second body of significant literature is that which highlights how railroads created "skewed development" and "sectoral disequilibrium," whereby some regions were relegated to the position of commodity suppliers. ${ }^{22}$ That both bodies of literature are relevant is indicative of Queensland's economic situation in the nineteenth century's closing years.

\section{Reckless Gambles: Locating Queensland's Experience}

Of America's first transcontinental railway, the Union Pacific, Klein observed that it "amounted to a reckless gamble for high stakes at long odds." ${ }^{23}$ Australia's railways were also immense speculative ventures. In Queensland, the $£ 17.6$ million (US $\$ 85.6$ million) invested in railways between 1864 and 1890 exceeded the combined investment in agriculture, the pastoral sector, mining, manufacturing and nonresidential construction ( $£ 15.9$ million or US $\$ 77.3$ million). ${ }^{24}$ This produced a disproportionately large railroad network as mileage grew to 2,205 miles in 1890 / 91 and 2,904 miles in 1900-01. During the same period, Queensland's population increased from 73,578 to $493,800 .{ }^{25}$

Queensland's disproportionate investment is indicated in Figure 1, which compares Queensland's per capita mileage with that for Australia and the United States as a whole as well as three other regions, namely Victoria and the American Southwest (Missouri, Arkansas, Kansas, Texas, Colorado, Oklahoma, New Mexico) and Northern Plains (Iowa, Minnesota, Nebraska, Wyoming, Montana and the Dakotas). ${ }^{26}$ By $1890-91$ Queensland's per capita mileage $(5.6$ per 1,000) was well above that for the next highest region, the Northern Plains, which boasted 5.3 miles per 1,000 residents. Moreover, while the latter's per capita mileage declined to 4.8 miles per 1,000 residents at century's end, Queensland's increased to 5.9 miles per 1,000. Admittedly, absolute mileage in 1900 was much higher in both the American Southwest (37,521 miles) and Northern Plains (32,104 miles). So too was population, the former region boasting 10.1 million and the latter 6.7 million. ${ }^{27}$ Nevertheless, the size of Queensland's railways, relative to population, logically suggests that they played a disproportionately important role in the colony's development.

The primary purpose of many New World railways was "developmental," it being expected that custom would follow behind laid track. To what extent was this

22. Stromquist, "Railroad Labor," 623-48; Butlin, Investment in Australian Economic Development, 407-408.

23. Maury Klein, Union Pacific, 1860-1893 (Minneapolis: University of Minnesota Press, 2006$), 34$.

24. Calculated from G. J. R. Linge, A Geography of Australian Manufacturing 1788 to 1890 (Canberra: ANU Press, 1979), 210-11, 415-16, 594-95, 676-77. Conversion from sterling to US dollars via, http: / / www.measuringworth.com/.

25. C. H. Knibbs, Commonwealth Yearbook, 1919 (Melbourne: Commonwealth Printer, 1920), $98,634$.

26. The aggregation of states cited reflects nineteenth century railroad statistical usage.

27. Calculated from US Department of Commerce and Labor, Statistical Abstract of the United States, 1905 (Washington, D.C.: Department of Commerce and Labor, 1906), 504; Henry Varnum Poor, Manual of the Railroads of the United States, 1902 (New York: V. H. and H. V. Poor, 1903), vii-vii, L. 
Figure 1: Comparative Mileage, $1870 / 71$ to $1900 / 01$

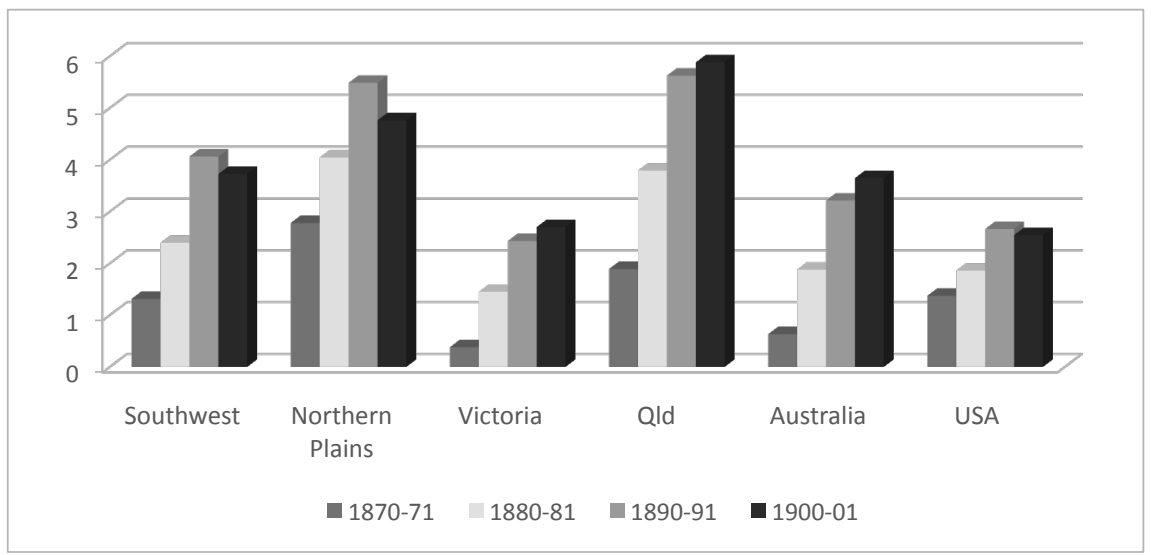

Sources: US Department of Commerce and Labor, Statistical Abstract of the United States, 1905 (Washington, D.C.: Department of Commerce and Labor, 1906), 504; Henry Varnum Poor, Manual of the Railroads of the United States, 1902 (New York: V. H. and H. V Poor, 1903), vii-vii, L; C. H. Knibbs, Commonwealth Yearbook, 1919 (Melbourne: Commonwealth Printer, 1920), 634

Figure 2: Comparative Earnings per Mile (US Dollars), 1885-95, Mid-Atlantic, Southwest, Northern Plains, Queensland and Victoria

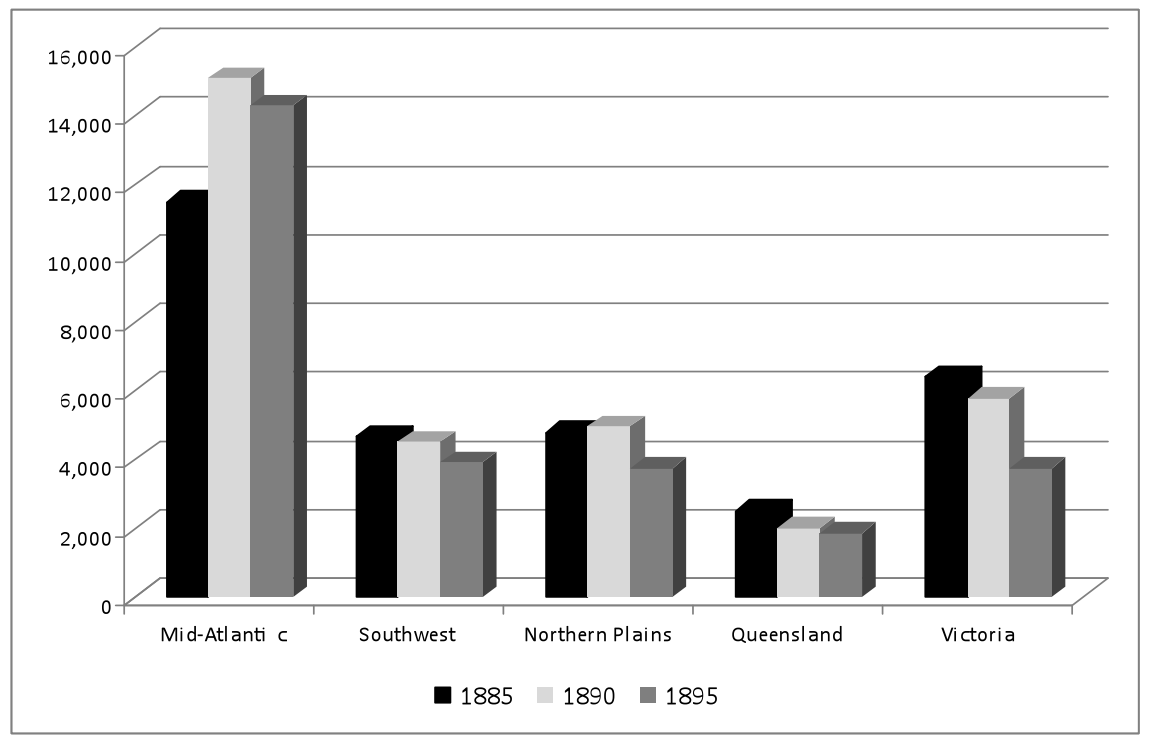

Sources: Henry Varnum Poor, Manual of the Railroads of the United States 1891 (New York: V. H. \& H. W. Poor, 1892), xi-xv; Henry Varnum Poor, Manual of the Railroads of the United States 1896 (New York: V. H. \& H. W. Poor, 1897); F. Curnow, "Report of the Queensland Railway Commissioner, 1886," QVP 3 (1887); John Mathieson, "Report of the Queensland Railway Commissioners, 1890," QVP 3 (1891); John Gray, "Report of the Queensland Railway Commissioners, 1896-97," QVP 4 (1897); Roger Speight, "Report of the Victorian Railway Commissioners, 1890-91," Victorian Parliamentary Papers (VPP) 5 (1891); John Mathieson, “Report of the Victorian Railway Commissioners, 1896-97," VPP 4 (1897) 
hope borne out in Queensland? In Figure 2 we explore this question by comparing per mile operating earnings of Queensland, measured in US dollars, between 1885 and 1895 with Victoria and three US regions: the Southwest, the Northern Plains and the Mid-Atlantic (New York, New Jersey, Pennsylvania, Delaware and the District of Columbia). While the Northern Plains and the Southwest shared Queensland's rural-orientation, Victoria and the Mid-Atlantic are exemplars of more industrialised societies - although Victoria's freight traffic became more rural in orientation as it expanded into the grain-growing Mallee and Wimmera regions. As can be seen in Figure 2, rural orientation was associated with low per-mile earnings. Queensland's performance was most dire, gross receipts per mile receipts falling from US $\$ 2,510$ in 1885 to US $\$ 1,869$ in 1895 .

To what can we ascribe Queensland's poor performance? As Figure 3 indicates, the problems that confronted Queensland's railways by 1890 were associated with its transformation from a system that primarily hauled wool into one that mainly carted corn and, more particularly wheat, from the Darling Downs and the agricultural southeast. This exposed not only railroad finances but also the communities located along the network to the vagaries of global grain markets.

While Australian historians long believed that the industral crises that characterised the 1890s was caused by falling wool prices in truth, as Svensen's study of the Queensland pastoral industry revealed, wool growing continued to prosper until the Federation Drought (1895-1903) devastated flock numbers. ${ }^{28}$ In consequence, the production and transport wool remained lucrative business in the 1890s. Although, as Figure 4 indicates, the per ton income obtained from wool haulage declined over time, as late as 1898 / 99 the Queensland Railway Department grossed ten times more for transporting a ton of wool (US \$16.68) than it did from hauling a ton of agricultural produce (US \$1.65). The core problem confronting Queensland's railroads was, therefore, not so much declining wool income but rather the rising tonnage of agricultural produce, most notably grain, for which there was little payment. Moreover, as Figure 4 demonstrates, the average income from hauling each ton of agricultural freight moved remorselessly downwards, falling from US \$4.69 in 1884 to a low of US $\$ 1.39$ in 1898/99.

The declining per ton value of Queensland's agricultural freight business is indicative of a problem that confronted rurally-oriented railroads throughout the New World as the global benchmark for wheat, the London "Gazette price," fell by 41.5 per cent between 1881 and 1901. Regional declines broadly followed this pattern. Amid violent year to year fluctuations, the "Chicago" wholesale benchmark fell from US \$1.175 in 1882 to US $\$ 0.71$ in 1900, a decline of 39.6 per cent. ${ }^{29}$ While reliable figures for Queensland wheat prices are unavailable before 1885, it is evident that "Brisbane" wholesale prices traced global fluctuations, falling from US \$1.12 in 1885 to US $\$ 0.73$ in $1900 / 01$ (a 34.8 per cent decline)..$^{30}$ To add to the woes of railroad

28. See Brian Fitzpatrick, A Short History of the Australian Labor Movement (Melbourne: Macmillan, 1968), 113-15; Mark Hearn and Harry Knowles, One Big Union: A History of the Australian Workers Union 1886-1994 (Melbourne: Cambridge University Press, 1996), 26-27. In contradiction, Stuart Svensen, The Shearers War (St Lucia: University of Queensland Press, 1989), 28.

29. Edgards Dunsdorfs, The Australian Wheat-Growing Industry 1788-1948 (Melbourne: Melbourne University Press, 1956), 115; Henry Wallace, Agricultural Prices (Des Moines: Henry A. Wallace Publishing, 1930), 123-24.

30. For 1897-1901, Queensland statistics came from the Queensland Department of Agriculture's Annual Reports, published in Queensland Votes \& Proceedings (hereafter QVP). Earlier years are drawn from either Ministerial statements read into the QPD or from Pugh's Almanac, accessed September 2015, http: / / www.textqueensland.com.au/pughs-almanac. 
Figure 3: Queensland Freight Tonnage, Wool and Agricultural, 1882-1900/01*

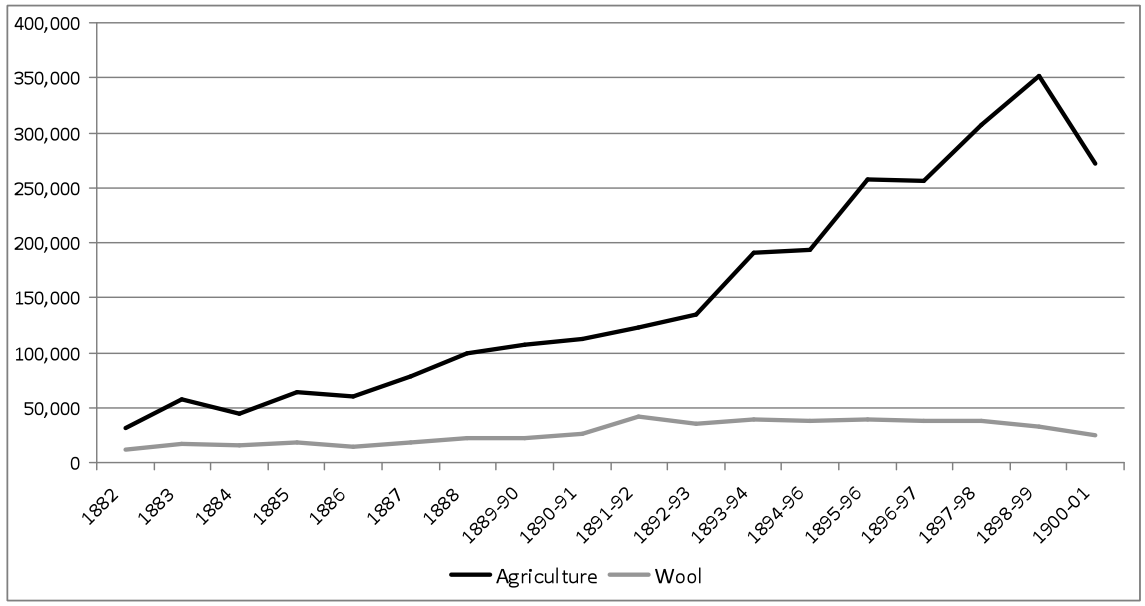

${ }^{*}$ Financial year recording from 1889

Sources: Curnow, "Report of the Queensland Railway Commissioner, 1886"; Mathieson, "Report of the Queensland Railway Commissioners, 1890"; Gray, "Report of the Queensland Railway Commissioners, 1896-97”; John Gray, “Report of the Queensland Railway Commissioners, 1900-01," QVP 4 (1901)

Figure 4: Per Ton Income (US Dollars) for Queensland Wool and Agricultural Produce Haulage, 1882-1900/01*

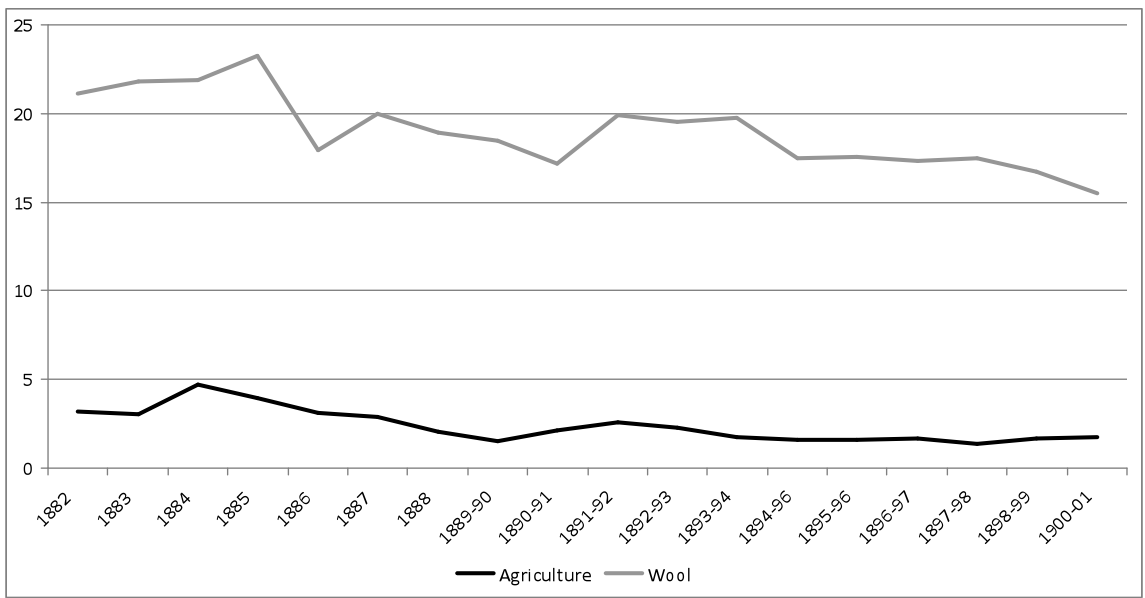

${ }^{*}$ Financial year recording from 1889

Sources: Curnow, "Report of the Queensland Railway Commissioner, 1886"; John Mathieson, "Report of the Queensland Railway Commissioners, 1890"; Gray, "Report of the Queensland Railway Commissioners, 1896-97"; Gray, "Report of the Queensland Railway Commissioners, 1900-01" 
Figure 5: Per Ton Freight Income (US Dollars), Northern Plains, Southwest and Queensland, 1882-1900*

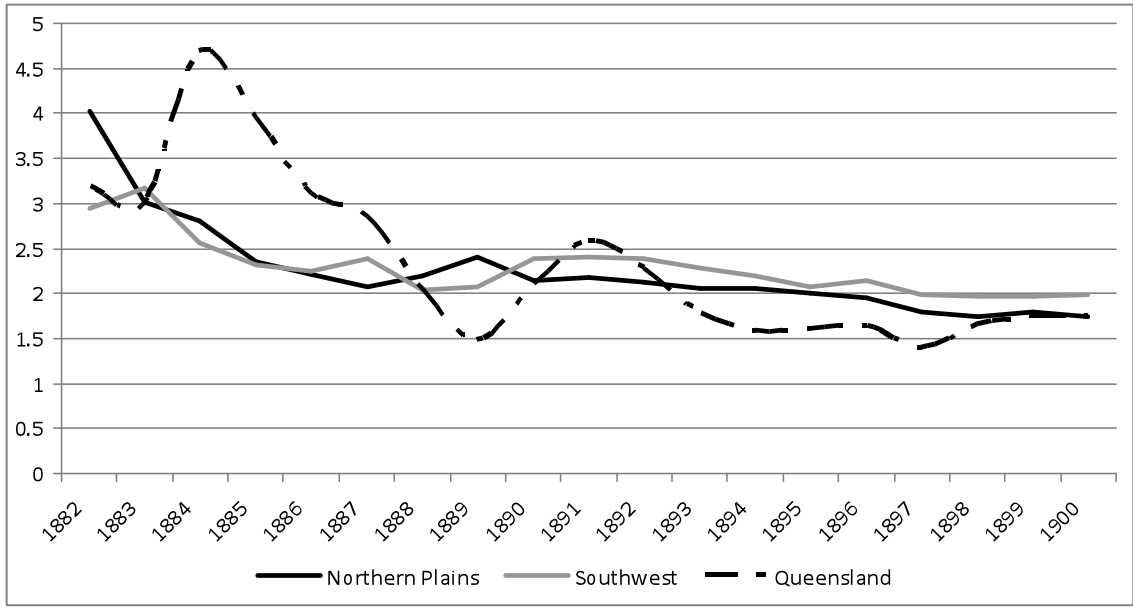

* For Queensland, financial year recording was used from 1889

Sources: Poor, Manual of the Railroads of the United States 1901; Curnow, "Report of the Queensland Railway Commissioner, 1886"; Mathieson, "Report of the Queensland Railway Commissioners, 1890"; Gray, "Report of the Queensland Railway Commissioners, 1896-97"; Gray, "Report of the Queensland Railway Commissioners, 1900-01"

shippers, political agitation by farmers magnified the downward pressure on freight rates. That there was a common factor at play in the railroads of Queensland and the American West is suggested in Figure 5, which compares Queensland's per ton agricultural freight income with the per ton freight income received in the American Southwest and Northern Plains between 1882 and 1900. All three regions show a like pattern, the modest rebound in 1889/90 corresponding to a brief recovery in wheat prices.

From the above discussion it is evident that the development of Queensland's railroads cannot be understood apart from global commodity markets. By seeking to use Queensland's railroads for "developmental" purposes, most particularly agricultural settlement, the colony's leaders inadvertently exposed the economy to the same deflationary pressures that were experienced by many US farmers and railroad shippers. Despite these commonalities, Queensland's geographic peculiarities meant that its railroads developed in some unusual ways.

\section{Railway Workforce Distribution, 1880-1901}

Queensland's railways differed from those of the American West and Australia's southern colonies in that they did not emanate from central hubs. While Brisbane was, following its connection with Ipswich in 1878, the easternmost termini of the southern system, the major repair facility for south-eastern traffic was still found in Ipswich. In Central Queensland, a separate trunk system from Rockhampton reached Barcaldine in 1886 and Longreach in 1892. The northern trunk line from Townsville reached Hughenden in 1887. In addition to these "trunk" or "pastoral" lines, there were eight "local" systems in 1890. Of these, that based upon Maryborough - and servicing the Wide Bay region with its gold fields (Gympie, Mount Perry), coal mines 
(Howard) and sugar plantations - was most significant. Other systems extended from Cairns, Normanton and Cooktown. Despite the growth in these regional systems, however, the prime beneficiaries of post-1880 expansion were found in the southeast, where Brisbane, Ipswich and Toowoomba were linked to Gympie in the north, Southport to the south and Wallangarra on the NSW border. The south-east also benefited from "agricultural" lines through the Darling Downs and the rich valleys in the Brisbane-Ipswich hinterland (see Map).

Emanation from multiple coastal or near coastal points had a number of effects. Most importantly, the railways built upon earlier commercial relationships, wherein coastal towns existed primarily as collection and distribution points for their rural hinterlands. Secondly, having trunk lines that headed west from the coast meant that the length of each system was much shorter than would have been the case with a Brisbane-based network. Shorter lines also made it easier to staff each system with workers based in the eastern termini, minimising recruitment in western regions characterised by labour scarcity. Railroad manufacture and repair was also concentrated in either Brisbane or, more particularly, the provincial hubs: Ipswich, Toowoomba, Maryborough, Rockhampton and Townsville. Following Parliament's decision to privatise work in 1879, maintenance was largely devolved to regional firms. W. Porrit \& Co. (Toowoomba), Burns and Twigg (Rockhampton), Shillito \& Son, Springall \& Frost (Ipswich), the Queensland Carriage Company (Brisbane) and, above all, Maryborough's Walker and Co. all obtained large contracts. ${ }^{31}$ The employment consequence of this can be ascertained from the fact that in 1901 Ipswich and Maryborough, with populations of 15,246 and 12,900 respectively, boasted (by Queensland standards) many metal workers, the former claiming 685 and the latter 562. By contrast, Brisbane, with 119,428 inhabitants, possessed 1,393..$^{32}$ However, although the Railway Department reported in 1883 that manufacture had been "wholly abandoned" in the government workshops, ${ }^{33}$ the provincial facilities subsequently witnessed a renaissance as the private workshops failed to carry out all the necessary work. In consequence, Ipswich Workshop job numbers rose from 212 in 1877 to 260 in 1887. In 1887, Maryborough's workshop also engaged 36. The workshops of Rockhampton and Townsville employed 76 and 56 respectively. ${ }^{34}$

Despite Queensland's rural orientation, the colony's railways were in job terms a predominantly urban phenomenon. This is demonstrated in Figures 6 and 7. In Figure 6, utilising census returns in which we group railroad-affected districts into six categories - western pastoral, mining, south-east agricultural (including the Darling Downs), the sugar districts, the eastern rail hubs and Brisbane - we trace the regional location of the traffic workforce for 1886, 1891 and $1901 .{ }^{35}$ In Figure

31. A. O. Herbert, “Rolling-Stock Ordered on Queensland Railways since 1879," QVP 4 (1883): 1761-62.

32. Ninth Census of Queensland, 1901, x, 268-69.

33. Herbert, "Rolling-Stock," 1761.

34. Robert Philp, "Select Committee Report into Management of Southern and Western Railway," QVP 2 (1877): 476; F. Curnow, “Report of Queensland Railway Commissioner, 1886," QVP 3 (1887): 1008-09.

35. For the purpose of this study, "western pastoral" comprises: Aramac, Balonne, Blackall, Bowen, Charleville, Cunnamulla, Clermont, Cloncurry, Diamantina, Gladstone, Hughenden, Leichardt, Marathon, Maranoa, Peak Downs, Springsure, St Lawrence and Warrego census districts; "mining" comprises: Burke, Croydon, Etheridge, Gympie, Herberton, Kennedy, Mt Morgan and Stanthorpe census districts; "southeast agricultural" comprises: Central Darling Downs; Western Darling Downs, Southern Darling Downs, Northern Darling Downs, Dalby, Fassifern, Highfields, Stanley and Warwick census districts; "sugar districts" comprise: Bundaberg, Cairns, Cardwell, Cook, Logan, Mackay, Tiaro and Wide Bay; "Brisbane" includes Caboolture, East Moreton, Nundah, Oxley East and Toowong census districts; "Ipswich" includes West Moreton and Oxley West census districts; "Rockhampton" includes Westwood census district. 
Figure 6: Regional Distribution of Queensland Traffic Workforce, 1886-1901

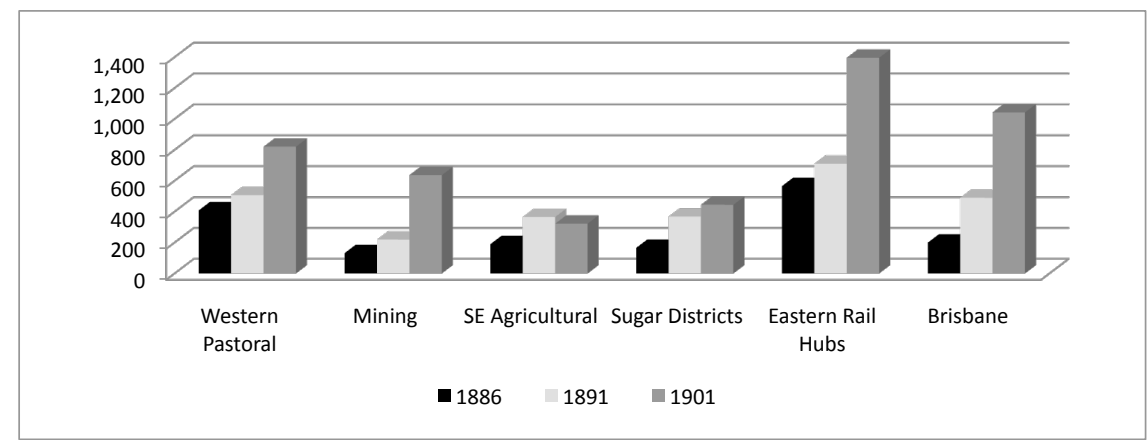

Source: Queensland Censuses 1886, 1891, 1901

Figure 7: Distribution of Queensland Engine-Crew Workers, 1886-1901

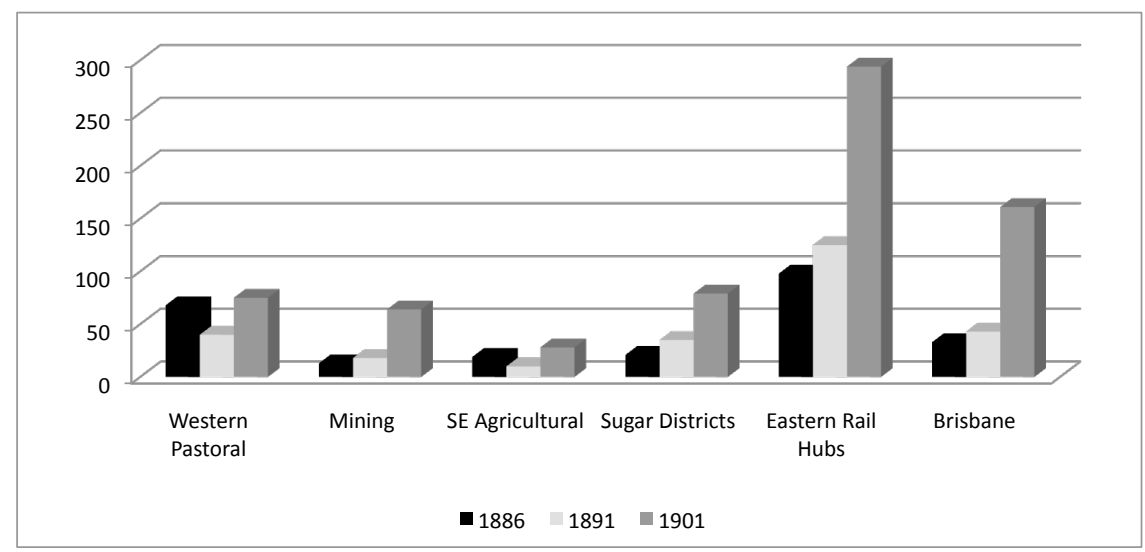

Source: Queensland Censuses 1886, 1891, 1901

Figure 8: Railway Engine-Crew Workforce in Major Provincial Hubs, 1886-1901

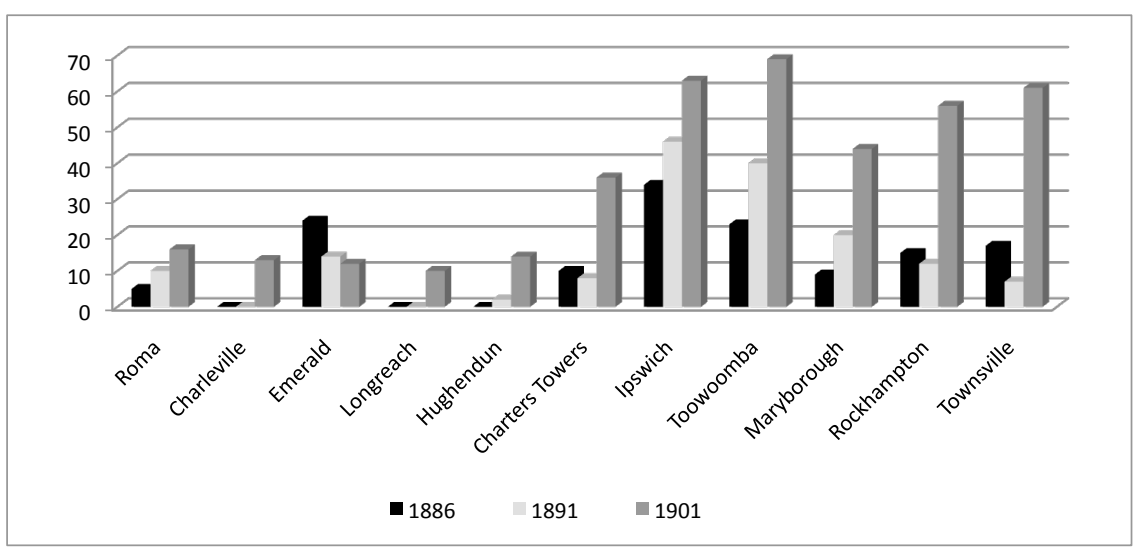

Source: Queensland Censuses 1886, 1891, 1901 
7, again utilising census returns, we consider the urban location of Queensland's engine-crews as this is the prime indicator of train starting and finishing points. As Figure 6 suggests, in 1886, workers residing in either Brisbane or one of the five eastern hubs - Ipswich, Toowoomba, Maryborough, Rockhampton and Townsville - comprised 45.6 per cent of the traffic workforce and 52 per cent of engine-crew employees. By 1901, 60.6 per cent of the traffic workforce and 71.4 per cent of enginecrews resided in these six centres.

Toowoomba's advance is particularly striking, the town employing a larger engine-crew workforce than any other regional centre by 1901 (see Figure 8). Geography was the key to this success. Atop the Main Range, Toowoomba was ideally placed as a distribution point, linking southern coastal towns to not only the Darling Downs, the Maranoa and the Warrego regions to the west but also Warwick, Stanthorpe and the NSW border to the south. Toowoomba also benefited from improved technology, the Railway Commissioners reporting the introduction "of a much heavier type" of locomotive on trunk lines during 1889-90 (older machines were reallocated to Brisbane's suburban service). ${ }^{36}$ These new locomotives further reduced the need for western crew changes. Similar outcomes are apparent in Central Queensland where Rockhampton was the main beneficiary of the system's westward advance. By 1901, Rockhampton's engine-crew workforce was almost four times bigger than in 1886. Its traffic workforce was more than two and a half times larger. By contrast, the combined engine-crew workforce of the two western hubs, Emerald and Longreach, was less than that possessed by Emerald alone in 1886. ${ }^{37}$ Similar trends were found on the northern trunk system, where the main employment beneficiaries of expansion were Charters Towers and, more particularly, Townsville. Such results highlight that, paradoxically, the main direct employment benefit of increased rural mileage was found in established coastal or near coastal cities, rather than in the West.

\section{The Railways and Queensland's Social Structure, 1880-1901}

Even before the railways were constructed, the peculiar contours of Queensland society were evident as economic activity revolved around western pastoralism, northern mining and agriculture. Railroad development nevertheless had profound effects. Positively, the railways nullified many of the effects of distance. The most obvious beneficiary of this was the rural population of the Darling Downs and the well-watered south-east; an area that saw farming numbers treble (from 2,918 to 8,978 ) between 1886 and 1901 as branch lines radiated out. However, while the railways reduced the cost of shipping primary commodities "down the line," they also lowered the cost of moving people and merchandise "up the line." The tendency of railway development to truncate the emergence of a diversified economy is indicated in Figures 9-12, where in districts directly affected by railroad expansion we trace employment in four sectors - metal manufacture, food and drink making, financial services, and merchandise trade (including storekeeping).

In metal manufacturing, as Figure 9 indicates, employment either lagged behind or barely kept pace with population increases in every regional grouping. Among the

36. John Mathieson, “Report of Queensland Railway Commissioners, 1890,” QVP 3 (1891): 481.

37. Queensland Government, Eighth Census of Queensland, 1891 (Brisbane: Queensland Government Printer, 1892), 188-89. 
Figure 9: Regional Distribution of Metal Manufacturing Employment in Railway Serviced Districts, 1886-1901

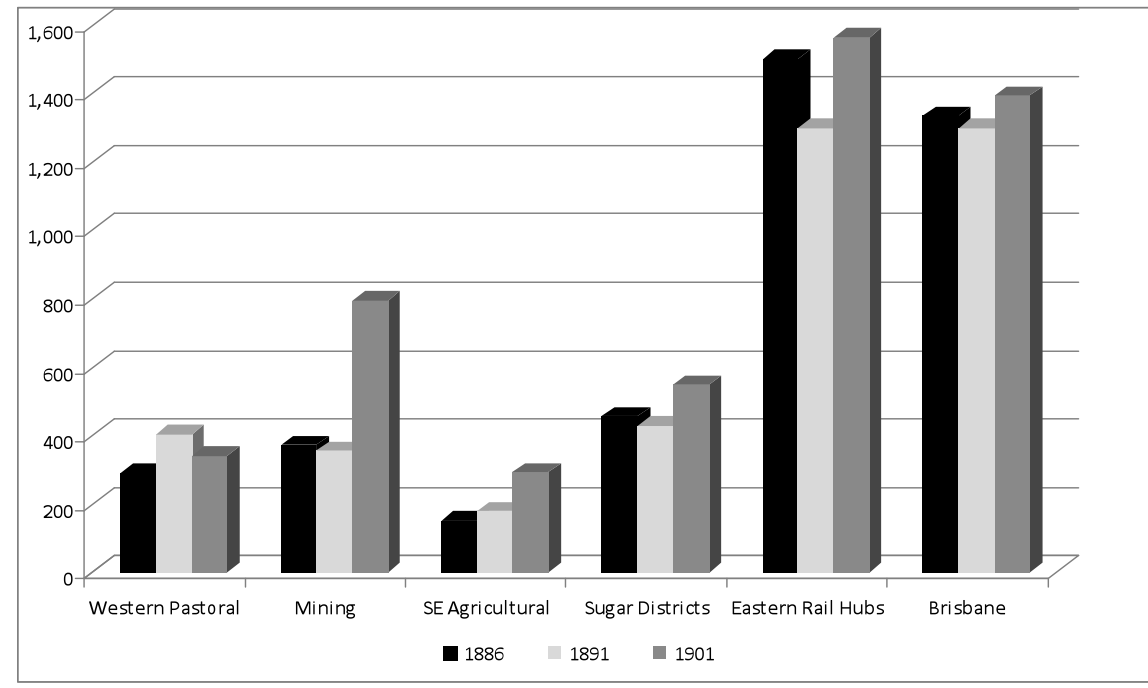

Source: Queensland Censuses 1888, 1891, 1901

Figure 10: Regional Distribution of Employment in Food and Drink Making in Railway Serviced Districts, 1886-1901

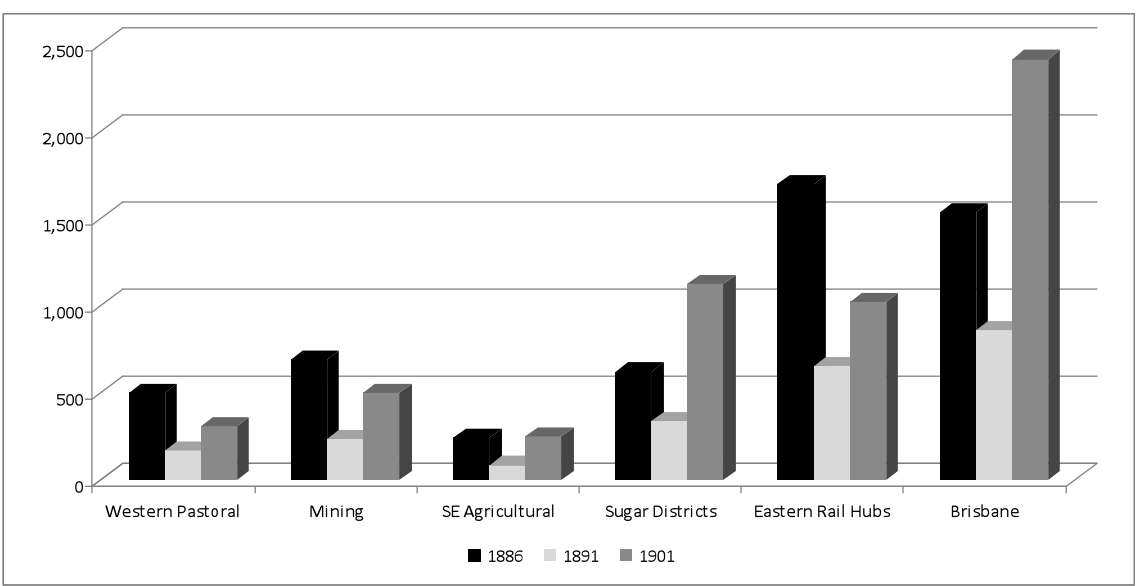

Source: Queensland Censuses 1888, 1891, 1901 
Figure 11: Regional Distribution of Financial Employment in Railway Serviced Districts, 1886-1901

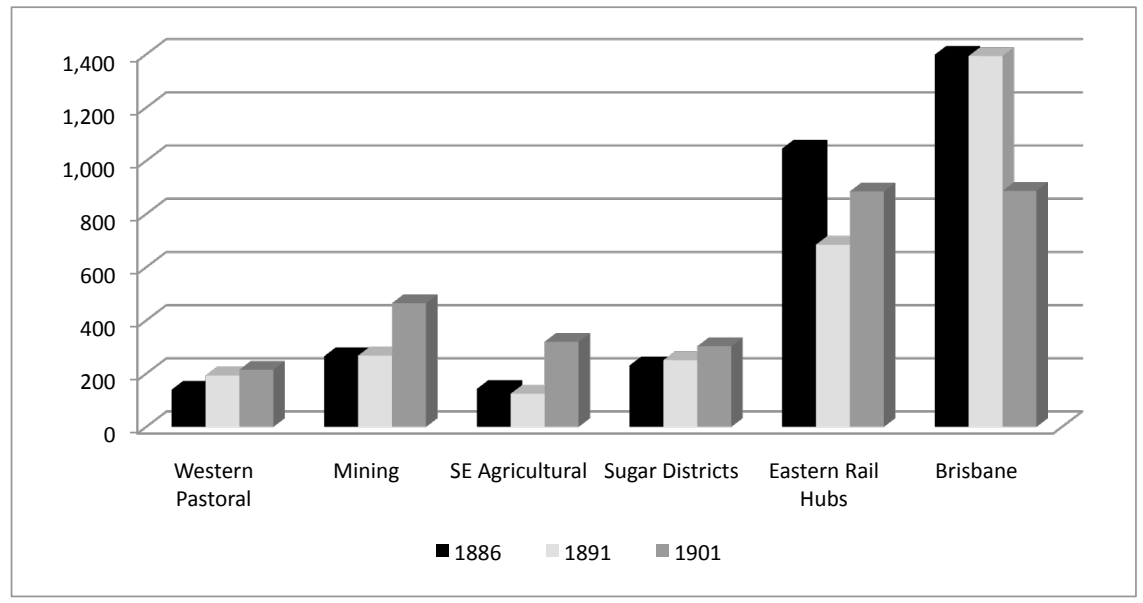

Source: Queensland Censuses 1888, 1891, 1901

Figure 12: Regional Distribution of Employment as Merchants and Storekeepers in Railway Serviced Districts, 1886-1901



Source: Queensland Censuses 1888, 1891, 1901 
worst performers were Brisbane and the eastern hubs - towns that boasted the bulk of Queensland's metal manufacturing workforce. Despite the combined population of the eastern rail hubs almost doubling to 106,943, and that of Brisbane and its environs rising by two-thirds to 118,488 , the increase in their metal trade labour force was negligible. This suggests these towns increasingly became mere conduits, on-shipping metal goods made elsewhere (Queensland, for example, imported all its iron and steel rails).

As Figure 10 reveals, similar trends to those discerned in metal wares are evident in food and drink making. Admittedly, figures for 1886 overstate employment by including those trading in food and drink as well as those engaged in manufacture. Later censes only included manufacturing workers. Even allowing for this, however, it is evident that food and drink making provided only modest additions to employment. Outside the sugar districts, only Brisbane witnessed job growth. This suggests that the railroads facilitated displacement of locally-made fare by Brisbane product. ${ }^{38}$

Increasing dependence on imported supply is also evident when, in Figure 11, we turn our attention to financial services, where a sharp decline in employment in the eastern rail hubs and in Brisbane was partly offset by increased work in rural and mining districts. It was not, however, simply the distribution of jobs that changed. It was also the very nature of financial employment. In 1886, financial and commercial services were still largely provided by local firms and agents. By 1901, this had changed as improved communications allowed banks headquartered outside Queensland to dispense with Brisbane-based offices in favour of country ones. In Hughenden, for example, only one person provided financial services in 1886. By 1901, the town had 15 such people. Of these, 11 were employed by banks. The major beneficiary of the reorganisation of financial activity, however, was Toowoomba. Unlike the other eastern hubs, all of which suffered sharp employment declines (Ipswich, for example, saw finance service employment fall from 388 to 214 between 1886 and 1901), Toowoomba's employment grew from 77 to 215 . This cemented Toowoomba's place as the main source of finance for the pastoral south-west. ${ }^{39}$

The suspicion that Queensland railroad expansion facilitated reliance on imported goods and services is reinforced when, in Figure 12, we turn our attention to employment as either a merchant or storekeeper (or employee of such people). In every region touched by the railways, those so engaged expanded at a far faster rate than any other form of work. In the pastoral districts, those working as pastoral workers or squatters increased by 35.9 per cent to 8,939 between 1886 and 1901 whilst merchant and storekeeper numbers grew by 270 per cent to 1,839. It was, however, in Brisbane and the other eastern hubs that the most phenomenal expansion of mercantile employment occurred. Whereas in 1886 the number of metal workers alone overshadowed those working as merchants and storekeepers, by 1901 the latter easily exceeded the combined number of those employed in railway traffic work, food and drink making and metal work..$^{40}$ Perversely, the greater the contribution of

38. Seventh Census of Queensland, 1886, 180-93; Eighth Census of Queensland, 1891, 188-90; Ninth Census of Queensland, 1901, 264-66.

39. Ninth Census of Queensland, 1901, 258-59.

40. Ibid 
the railways to a town's economy, the more closely it tended to resemble a "market town" under the sway of merchants and storekeepers.

\section{Queensland's Merchant Towns and Organised Labour}

Writing of the towns dotted along the railroad network of the American West during the late nineteenth century, Stromquist observed that many were "merchant towns" in that, although they had come to depend upon the railroads for their well-being, they were dominated by a "well-organized elite" composed largely of mercantile interests. ${ }^{41}$ As is evident from the previous section, by the 1890s the great bulk of Queensland's "railway towns" corresponded to what Stromquist would refer to as "merchant towns," the partial exceptions being Maryborough (where metal workers outnumbered merchants and storekeepers) and, to a lesser degree, Brisbane. The author's ambivalence towards Brisbane in the face of the soaring mercantile employment noted in Figure 11 reflects awareness of what Ronald Lawson referred to, in his history of the city during the 1890s, as an "explosive expansion" of textile work brought about by the protective tariffs enacted by Mcllwraith in 1888. The expansion of such work caused Lawson to designate Brisbane an "industrial" city, thereby putting himself at odds with his fellow urban historians, John McCarty and Graeme Davison, both of whom declared nineteenth century Brisbane to be a "commercial" town..$^{42}$ However, while the simplistic designation of any developing city is problematic, Lawson's categorisation of Brisbane as an "industrial" city is even more dubious than its classification as a "merchant" or "commercial" city. As Lawson himself recognised, most Brisbane factories "were very small" affairs wherein owners earned "little more than those of their employees." 43

The gulf between Brisbane and the northern hemisphere's industrial cities is also indicated by the social confines within which urban labour operated. As my study of pre-1890 Brisbane indicated, most early unions only survived with employer support. When the Eight Hour movement emerged in 1857 it did so under the patronage of John Petrie, Brisbane's leading builder. An employer, William Galloway, founded the Brisbane Trades and Labour Council in 1885. When support for more militant forms of unions emerged around 1890 this reflected the growth of itinerant workforces on the waterfront and in construction, rather than changes among Brisbane's small industrial workforce. In this regard, the expulsion of Galloway from the Federated Seamen's Union of Australia (FSUA) - an organisation whose Brisbane branch he had founded in 1879 - proved a seminal moment. Led by Charles Seymour, an admirer of William Lane, the FSUA and its ally, the Waterside Labourers' Union (WLU), provided the nucleus around which radical unionists subsequently coalesced. This culminated in the formation of the Lane-inspired Australian Labour Federation in 1889, an organisation that began publication of the Brisbane Worker with Lane as editor. ${ }^{44}$ We should, however, not exaggerate changes. During the Maritime Strike

41. Stromquist, Generation of Boomers, 145.

42. Ronald Lawson, Brisbane in the 1890s (St Lucia: Queensland University Press, 1973), 51, 321; Graeme Davison, "Explanations of Urban Radicalism: Old Theories and New Histories," Australian Historical Studies, no. 70 (April 1978): 68-87; John McCarty, “Australian Capital Cities in the Nineteenth Century," Australian Economic History Review 10 (September 1970): 107-37.

43. Lawson, Brisbane in the 1890s, 45, 61.

44. Bradley Bowden, “'Harmony ... between the Employer and Employed': Employer Support for Union Formation in Brisbane, 1857-1890," Labour History, no. 97 (November 2009): 105-22. 
of 1890 the only Brisbane workers to engage in prolonged industrial action were members of the FSUA, the WLU and a minority of carters. Elsewhere, the strike galvanised an anti-union backlash, it being reported that: "Nearly every merchant in the city has joined the Employers' Association." ${ }^{45}$ Within a few weeks the strike had collapsed. Organised labour also found little joy on the political front. In 1893, in its first general election showing, Labor won only two of the 13 seats available in Brisbane and its suburbs. ${ }^{46}$

Theoretically, metropolitan labour's weaknesses should have been offset by the unionisation of railway workers in the major provincial centres. Here, unionism gained an early foothold when British fitters and turners recruited to staff the Ipswich workshops formed a branch of the Amalgamated Society of Engineers (ASE) prior to arrival. By 1879, ASE branches were also reported at the railway workshops and metal foundries of Brisbane, Maryborough and Toowoomba. ${ }^{47}$ By 1886, most engine-crew members were members of the Locomotive Engine-Drivers, Firemen and Cleaners' Association (LEFCA) ${ }^{48}$ Moreover, by January 1890 an all-grades union, the Queensland Railway Employees Union (QREA), had recruited 3,000 members. Of Queensland's unions, only the Queensland Shearers' Union (QSU) was larger. ${ }^{49}$ Despite such apparent strength, however, railway unionism reflected the societies that spawned it. In Ipswich, the site of Queensland's largest railway workshop, the power of the city's merchant families was all-pervasive..$^{50}$ So great was the authority exercised by "the old-established firms of Cribb \& Foote, Macfarlane \& Co., and the like" over "their humbler neighbours," the Brisbane Courier complained in 1879, that for "a large proportion of the community, individual liberty has ceased to exist." 51 While "labour" candidates were elected at Bundamba (an Ipswich mining hamlet) in 1888 and in Ipswich itself in 1894, these were deceptive indicators. The 1888 victory was only made possible by merchant rivalries. James Wilkinson, the victor in 1894, and Secretary of first the LEFCA and then the QREA, enjoyed the patronage of the Macfarlanes, one of Ipswich's great merchant families. Within a few years, Wilkinson was to break from Labor, successfully contesting elections on a conservative agenda.

In Rockhampton as well, Labor's initial success also came through collaboration with sections of the city's commercial interests, most of whom favoured a separate state with Rockhampton as its capital. Moreover, William Kidston, the city's dominant Labor figure, owned a book selling business. In gaining election in 1896, Kidston ran on a pro-separation agenda. The "only hope of progress in Queensland," he declared, "lay in the union of Labour men and Liberals of all shades of opinion." 52 Like Wilkinson, Kidston was to break from Labor, serving as Premier in anti-Labor governments between and 1906 and 1911.

Toowoomba was another railway town where merchants dominated. As Waterson recounted: “Toowoomba's history is ... one of the great urban bourgeois success stories." While an ex-convict, William Groom, was perennially elected,

45. Brisbane Courier, 23 August 1890, 5

46. Colin Hughes, "Labour in the electorates," in Prelude to Power: The Rise of the Labour Party in Queensland 1885-1915, ed. D. J. Murphy (Milton: Jacaranda Press, 1970), 76.

47. "Minutes of Evidence: Select Committee on the Railway Workshops," QVP 2 (1879): 538-39.

48. Queensland Times, 5 August 1886.

49. Boomerang, 18 January 1890.

50. Bowden, "Some Mysterious Terror"; Bowden, "A Time the Like of Which."

51. Brisbane Courier, 3 February 1879, 2.

52. Cited in D. J. Murphy, "William Kidston," in Murphy and Joyce, Queensland Political Portraits, 227. 
behind-the-scenes power lay with local "kings" drawn from resident squatters and well-to-do town merchants. When the Labor Party sought a Toowoomba presence it found few adherents..$^{53}$ In Maryborough, circumstance differed in that power was concentrated not in the hands of merchants but rather of John Walker and his partners in Walker and Co-Queensland's largest private sector manufacturer of locomotives and rolling stock. In the 1880s and 1890s, both of Maryborough's long-term parliamentarians, R. B. Sheridan and John Annear, were Walker and Co. associates, the latter serving as a partner in the company. Significantly, the tentacles of Walker and Co. extended into virtually every aspect of economic life. As Sheridan, one of the pro-Walker politicians noted: "There is no occupation a labouring man can fulfil that there is not an opportunity for his being employed by John Walker and Co." 54

Springing from merchant-dominated towns, the leaders of Queensland's railway unions articulated a conservative agenda. Addressing the LEFCA's annual meeting in 1886, Wilkinson, who was then the union's Queensland secretary, advised that there was not "anything of trade unionism about the association." Frederick Curnow, the Railway Commissioner, who attended the meeting, similarly declared that "if the society had been conducted on the basis of trade unionism" than he "would not [be] present." ${ }^{55}$ Ties between Wilkinson and the Commissioners were extended when the Parliament decided, in passing the State Railways Management Act 1888, to replace ad hoc arrangements with regulated employment. ${ }^{56}$ In implementing Parliament's wishes the Commissioners fostered an all-grades union. Shortly after the new act's passage, Wilkinson toured southern lines. With management's tacit approval, 1,400 were recruited. Returning to Ipswich, Wilkinson launched the QREA on 28 May 1889, becoming its General Secretary. He then recruited on the Central and Northern lines. By 1890, as noted earlier, the QREA boasted more than 3,000 members ${ }^{57}$ Despite this nominal strength, however, the QREA could only survive with management backing. When the Queensland Shearers' Strike erupted in 1891, this support evaporated. To suppress the strikers, the Commissioners directed Central line employees to act as "special constables." When 30 QREA members at Emerald refused, they were dismissed. Significantly, the leadership of the railway unions tacitly or actively endorsed such actions, the Commissioners singling out the LEFCA for "enjoining members of their Association to keep aloof from all disputes." ${ }^{58}$ Despite the QREA's passivity, in August 1891 the Commissioners demanded that station masters and other officers resign their QREA membership, an action seemingly driven by fear of further "wild-cat" QREA stoppages in pastoral areas. ${ }^{59}$ This led to the union's collapse, the QREA disappearing entirely in 1894 when Wilkinson resigned the Secretaryship to enter Parliament. Thereafter, management operated with a virtual free hand. When in 1893 , legislation mandated wage cuts of up to 25

53. Duncan Waterson, Squatter, Selector, and Storekeeper: A History of the Darling Downs 1859-93 (Sydney: Sydney University Press, 1968), 80, 233, 265-68.

54. QPD 44 (1886): 594.

55. Queensland Times, 5 August 1886; Bowden, "Some Mysterious Terror," 90-91.

56. Queensland Government Gazette, 7 November 1888, 861-71.

57. Boomerang, 1 June 1889; Worker, 1 April 1890, 15 June 1889, 18 January 1890, 10 August 1889.

58. John Mathieson, “Report of Queensland Railway Commissioners, 1891-92," QVP 3 (1892) 409.

59. Brisbane Worker, 8 August 1891. 
per cent in response to economic depression, these measures were meekly accepted by the workforce. ${ }^{60}$

\section{Railroad Development and Rural Society}

In rural areas, railroad development resulted in deep social fissures. Problems were first evidenced in wheat-growing as the Brisbane wheat price, reflecting global trends, fell from 4.5 shillings (US \$1.25) per bushel in 1885 to 3 shillings and 4 pence (US $\$ 0.94$ ) in 1887. As in the American West, where much of the anger of the Populist movement was directed against railroad freight rates, such falls fuelled rural protest. ${ }^{61}$ Across southern Queensland, it was observed, farmers "agitated for a reduction in rates." ${ }^{\prime 2}$ In parliament, their elected representatives, colloquially known as the "Darling Downs Bunch," replicated these complaints. The "Bunch's" leader, Arthur Morgan, declaring "that, with the exorbitant railway rates ... farmers could not send the produce to Brisbane and sell it at a profit." ${ }^{63}$ Relenting, parliament reduced the rate for shipping a ton of produce (for 180 kilometres) from 29.2 shillings (US $\$ 7.09$ ) in 1884 to 13.75 shillings (US \$3.35) in $1888 .{ }^{64}$ Such action merely encouraged increased farm output. This had disastrous effects for railroad finances as more carriages were filled with low-value produce. By 1890/91, working expenses, which had amounted to 47.4 per cent of gross revenues in 1883 , were consuming 72.8 per cent of each shilling earned. This left little for interest charges, which in 1890/91 amounted to 161.7 per cent of net earnings. ${ }^{65}$ Following a brief spike in wheat prices, railway management responded by increasing agricultural freight charges by 50 per cent to 18.25 shillings (US \$4.44) from 1891. In justification, the Minister for Railways emphasised that "carriage of agricultural produce" had become the "chief" cause of railway deficits. ${ }^{66}$

The 1891 rate hike caused unprecedented farm protest. Rallies were "held at intervals all over the Darling Downs." ${ }^{67}$ Once more, parliament reduced rates. However, as wheat prices declined further, the pressure mounted for additional cuts. After 1893, such demands were supported by Labor politicians. Wilkinson, the former LECFA and QREA secretary, was most vocal, condemning the government for trying to work the railroads for "direct profit." ${ }^{68}$ Such expressions underpinned commonalities of interest between Queensland Labor's conservative wing, which was sympathetic to small property owners, and the "Darling Downs Bunch." In 1903, such commonalities saw the replacement of the "Continuous Ministry" that had ruled Queensland since 1890 by a "progressive" coalition, in which Morgan (the "Bunch's" leader) served as Premier and Kidston as Treasurer. Farming interests were then placated by legislation granting them with extensive financial assistance.

60. QPD 70 (1894): 122-25; Bowden, "Some Mysterious Terror," 91.

61. See, in particular, Robert Higgs, "Railroad Rates and the Populist Uprising," Agricultural History 44 (1970): 291-98.

62. QPD 60 (1888): 147

63. QPD 52 (1887): 428

64. Ibid.; QPD 64 (1891): 1367-70.

65. Mathieson, “Report of Queensland Railway Commissioners, 1891-92," 492.

66. QPD 60 (1888): 147.

67. QPD 64 (1891): 366

68. QPD 74 (1895): 1422. 
Workers and their unions were rewarded with electoral reform, including the female franchise, and the passage of Queensland's first Workers Compensation Act. ${ }^{69}$

The benefits Labor obtained through alliance with farm interests reflected the more complex rural society that railroad development had left in its wake. Complexities were also apparent in pastoral districts, where the railways helped boost sheep numbers from 4.3 million to 21.7 million between 1861 and 1892. While, as noted earlier, historians long believed that wool was blighted by falling prices during the 1890s, in reality it remained in rude health for most of the decade. The 87.4 million pounds of wool shorn in 1896 was the third highest output in the industry's history, bettered only by the benign 1891 and 1892 seasons. ${ }^{70}$ While the average price obtained for each pound of "greasy" (unclean) wool fell from 9.65 pence (US \$0.19) in 1890 to a low of 6.75 pence (US $\$ 0.14$ ) in 1898 , such declines were offset by increased volumes from fewer sheep; an achievement that reflected improved breeding and fleece size. In consequence, the industry's peak receipts occurred not in 1889, traditionally regarded as the last of the "boom" years, but in 1893 when $£ 4,255,939$ (US $\$ 20,726,423$ ) obtained. Not until 1897 , when $£ 2,499,707$ (US $\$ 14,497,956$ ) was received amid worsening drought, did receipts fall below 1889 returns. ${ }^{71}$

Despite the continuation of lucrative wool receipts, the pastoral industry suffered from two problems: difficulty in managing a much larger shearing workforce and exposure to climatic adversity. Both problems resulted, in turn, from the industry's railroad-facilitated shift from its original Darling Downs' base to Queensland's western plains. While the exact composition of Queensland's western workforce remains a mystery, there is no reason to doubt Merritt's and Svensen's belief that most were itinerants who owed little loyalty to their employer. ${ }^{72}$ However, it is also evident that, where possible, pastoral employers sought to avoid engagement of such workers. Even the Railway Department much preferred local homesteaders as employees on the western plains, the Minister reporting in 1895: “The men who do the best work for the department are the men who look after their [own] herds and homesteads." ${ }^{73}$ Unfortunately, there were few such loyal homesteaders to go around in the pastoral west. Reflecting this, the QSU boasted 3,271 members within three years of its formation in 1887. Another 7,874 belonged to the Central Queensland Labourers' Union (CQLU). ${ }^{74}$ Even when subject to industrial defeat, the loyalty of the western pastoral workforce to the union cause was surprisingly resilient. While membership of the Amalgamated Workers' Union, formed by a merger of the QSU and CQLU, fell to 3,402 in the wake of the Shearers' Strike of 1894, it then rebounded. By 1898 the Amalgamated Workers' Union boasted 5,152 members, a figure not too far short of its pre-strike strength $(5,281) \cdot{ }^{75}$ Unfortunately for the union, climate was to prove a more difficult foe than the pastoral employers. As the Federation Drought took hold, membership declined from 5,152 in 1898 to 3,357 in $1901 .{ }^{76}$ Unlike the

\footnotetext{
69. Murphy, “William Kidston,” 221-61.

70. J. Hughes, “Queensland Agricultural and Pastoral Statistics, 1900,” QVP 4 (1901): 209-16.

71. The statistics cited are drawn from the annual reports in Pugh's Almanac, accessed September 2015, http: / / www.textqueensland.com.au/pughs-almanac.

72. John Merritt, The Making of the AWU (Melbourne: Oxford University Press, 1986), 43-49, 128-29; Svensen, The Shearers War, 39-47.

73. QPD 74 (1895): 1419.

74. H. Kenway, "The Pastoral Strikes of 1891 and 1894," in Murphy, Prelude to Power, 119.

75. Ibid.

76. Ibid., 123-24.
} 
losses suffered because of industrial defeat, there was to be no quick recovery, as sheep numbers fell from 19.6 million in 1896 to 10.4 million in 1900. In short, while the railways had helped make pastoral settlement on the western plains economically possible, they could not guarantee that long-term viability of occupancy. In this, as with other aspects of Queensland's railroad-driven development, employment was built on unstable foundations.

\section{Conclusion}

In the nineteenth century, the industrialising societies of the North Atlantic reshaped the globe, drawing in raw materials and sending out mass-produced manufactures in return. As with other New World societies, Queensland's railroad development cannot be understood apart from these global patterns of supply and demand. That Queensland's situation was far from unique, this study has argued, is apparent from the many similarities between Queensland circumstance and that found in the American Southwest and Northern Plains. By the late 1880s, Queensland's per capita mileage was virtually identical with that of the Northern Plains. In Queensland, as in the American West, agricultural commodities, most particularly grain, comprised the bulk of rural tonnage. As global grain markets were glutted by New World oversupply, prices for these agricultural commodities fell in like fashion. As prices plummeted, per ton freight income in Queensland and the American West also declined in near identical fashion (see Figure 5). Commonalities were also manifest in social remonstrations. In 1890, Queensland's railroads resembled their western US counterparts in having an organised workforce. The presence of an unhappy grain-growing population was another commonality. As with the Populist movement that swept the US western plains, protesting Queensland wheat farmers directed much of their anger at railroad freight rates. No natural friends of organised labour, these farmers and their representatives found common ground with elements of the newly-formed Labor Party, leading to the formation of a "progressive" coalition government in 1903.

If Queensland's railroads had commonalities with those in the American West, they nevertheless developed in some unique ways. In large part, peculiarities were the product of geography, Queensland benefiting from the fact that its agricultural and pastoral regions were comparatively close to the coast. In consequence, it made sense to construct lines servicing the interior not from central hubs, as occurred in southern colonies and the American West, but rather from established ports. This shaped Queensland society in three ways. First, westward railroads were associated with the concentration of railway employment in eastern hubs. Elsewhere, railways provided work for surprisingly few. Second, concentration in coastal or near coastal towns encouraged importation over local manufacture. The major beneficiaries of this were merchants and traders. Thus, whereas Stromquist delineated how westward US railway expansion produced two community types - "merchant towns" dominated by a merchant elite and "railway towns" within which railway employees and their industrial allies exercised hegemony ${ }^{77}$ - Queensland produced only "merchant towns." The unsurprising result was a railway workforce characterised by passivity. While many joined a (management endorsed) union, the QREA, in 1889/90, they

77. Stromquist, Generation of Boomers, 144-45. 
also abandoned it when management subsequently indicated displeasure. Passivity extended to the wider urban workforce, where socialism and militant unionism made few gains prior to 1900. The third, and most enduring, effect of Queensland railroad development was its reinforcement of what Butlin called sectoral disequilibrium, wherein the economy was built around a few trade-exposed (and climate-exposed) activities. Among organised labour's Queensland's ranks the first major casualty of this was the Amalgamated Workers' Union, the colony's largest union, which haemorrhaged members when the Federation Drought destroyed the pastoral industry's prosperity. Such losses, however, precipitated no reorientation of either the labour movement or of Queensland's rurally-orientated economy. Instead, both continued to display the effects of the colonial railroad development well into the twentieth century.

Bradley Bowden is Professor of Employment Relations at Griffith University and Chair Elect of the Management History Division of the Academy of Management. He is a longterm contributor to this journal, this article being his eleventh.

$<$ b.bowden@griffith.edu.au> 